\title{
\begin{tabular}{l|l} 
Mitraries & DSpace@MIT
\end{tabular}
}

\author{
MIT Open Access Articles
}

\section{Proof of Tacticity of Stereoregular ROMP Polymers through Post Polymerization Modification}

The MIT Faculty has made this article openly available. Please share how this access benefits you. Your story matters.

Citation: Hyvl, Jakub; Autenrieth, Benjamin and Schrock, Richard R."Proof of Tacticity of Stereoregular ROMP Polymers through Post Polymerization Modification." Macromolecules 48, no. 9 (May 2015): 3148-3152. (C) 2015 American Chemical Society

As Published: http://pubs.acs.org/doi/abs/10.1021/acs.macromol.5b00477

Publisher: American Chemical Society (ACS)

Persistent URL: http://hdl.handle.net/1721.1/108291

Version: Author's final manuscript: final author's manuscript post peer review, without publisher's formatting or copy editing

Terms of Use: Article is made available in accordance with the publisher's policy and may be subject to US copyright law. Please refer to the publisher's site for terms of use. 


\title{
Proof of Tacticity of Stereoregular ROMP Polymers Through Post Polymerization Modification
}

\author{
Jakub Hyvl, Benjamin Autenrieth, and Richard R. Schrock* \\ Department of Chemistry 6-331, Massachusetts Institute of Technology, Cambridge, \\ Massachusetts 02139
}

\begin{abstract}
Partial bromination or epoxidation has been used to prove the tacticities of several stereoregular polymers made through ROMP methods with well-defined Mo or W initiators. Tacticities were proven for cis,isotactic and cis,syndiotactic poly(norbornene), poly(3-methyl-3phenylcyclopropene), and poly(endo,anti-tetracyclododecene). Various limitations can prevent application of these proofs in general to stereoregular polymers prepared through ROMP.
\end{abstract}




\section{INTRODUCTION}

Ring-opening metathesis polymerization (ROMP) is a powerful method for the synthesis of polymers. ${ }^{1}$ It is most desirable that the structures so obtained be stereoregular, because desirable polymer properties (e.g., crystallization) often then emerge. In the last several years we have been developing molybdenum and tungsten catalysts for stereospecific (cis) ROMP, i.e., initiators that yield polymers with all $c$ is $\mathrm{C}=\mathrm{C}$ bonds and that have an isotactic or syndiotactic relationship between neighboring monomer units (dyads) in the polymer. ${ }^{2}$ Tacticities can be determined readily if the polymers are made from an enantiomerically pure monomer, e.g., enantiomerically pure dicarboalkoxynorbornadienes $\left(2,3-\left(\mathrm{CO}_{2} \mathrm{R}^{*}\right)_{2}\right.$-norbornadiene where $\mathrm{R}^{*}=$ $(1 R, 2 S, \quad 5 R)-(-)$-menthyl or (R)-(-)-pantolactonyl) or disubstituted norbornenes (2,3dicarbomethoxynorborn-5-ene, 2,3-dimethoxymethylnorborn-5-ene, and 5,6-dimethylnorborn-2ene). ${ }^{3,4}$ A chiral element breaks the symmetry (a plane or a $\mathrm{C}_{2}$-axis) that interconverts two backbone olefinic protons in a cis,isotactic or a cis,syndiotactic backbone structure and allows the two tacticities to be distinguished directly through homonuclear (proton/proton) correlation spectroscopy and decoupling experiments, as shown in Figure 1. This approach proves the structure of the chiral derivative (e.g., carbomenthoxy), but not necessarily an achiral analog (e.g., carbomethoxy). ${ }^{4}$

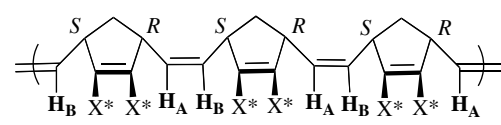

cis, isotactic

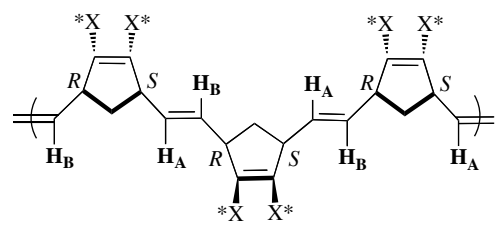

trans, isotactic

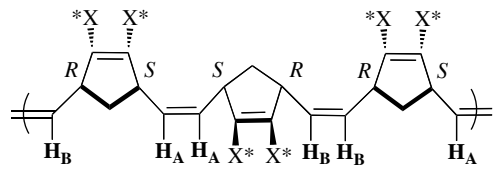

cis, syndiotactic

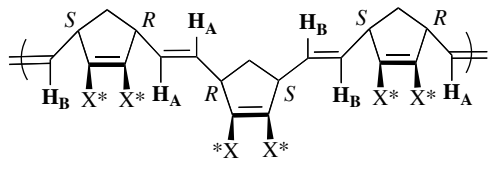

trans, syndiotactic

$\mathrm{X}^{*}=\mathrm{CO}_{2} \mathrm{R}$ where $\mathrm{R}=$ Menthyl or Pantolactonyl

Figure 1. The four stereoregular structures of menthyl and pantolactonyl ester derivatives of polymers prepared through ROMP of 2,3-dicarboalkoxynorbornadienes.

Recently we evaluated a variety of well-defined Mo-based and W-based alkylidene initiators for the stereoselective polymerization of norbornene (NBE), ${ }^{5}$ endo,antitetracyclododecene (TCD), ${ }^{5}$ endo-dicyclopentadiene (DCPD), ${ }^{6}$ and enantiomerically pure methyl-N-(1-phenylethyl)-2-azabicyclo[2.2.1] hept-5-ene-3-carboxylate, ${ }^{7}$ to give cis, isotactic or 
cis,syndiotactic structures. What are proposed to be cis,isotactic polymers made from achiral monomers (>98\%) are prepared employing certain Mo and $\mathrm{W}$ imido alkylidene initiators that contain a chiral, racemic, $\mathrm{C}_{2}$-symmetric biphenolate ligand; an example is $\mathbf{1}$ in Figure 2 . The chiral biphenolate ligand is proposed to force the monomer to add repeatedly to the same face of each $\mathrm{M}=\mathrm{C}$ bond that is formed in the polymerization process (enantiomorphic site control). More recently, cis,syndiotactic polymers have been prepared from monoaryloxide pyrrolide initiators; an example is $\mathbf{2}$ in Figure 2. These initiators enforce syndiotacticity through "stereogenic metal control" as a consequence of the monomer adding trans to the pyrrolide and the chirality at the metal inverting with each addition of monomer. Under these circumstances the monomer adds alternately to one $\mathrm{M}=\mathrm{C}$ face and then the other. ${ }^{2,8}$ The initiators in Figure 2 are examples from a much large selection of catalysts that were evaluated for the polymerization of NBE, ${ }^{5} \mathrm{TCD},{ }^{5}$ and DCPD. ${ }^{6}$ Initiator $\mathbf{1}$ yielded cis, isotactic polymers from all three monomers $\left(\mathrm{NBE},{ }^{5} \mathrm{TCD}^{5}\right.$ and $\left.\mathrm{DCPD}^{6}\right)$, while 2 yielded cis,syndiotactic polymers from all three monomers. It seems unlikely that many catalysts will be found that yield $>98 \%$ cis,syndiotactic or $>98 \%$ cis,isotactic polymers from a large and diverse collection of monomers, although that remains to be determined. Highly stereoregular polymers prepared from NBE, TCD, or DCPD have been hydrogenated to yield highly crystalline, relatively tactic saturated polymers. ${ }^{9}$

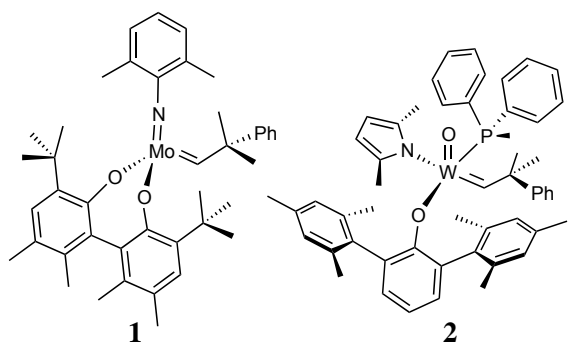

Figure 2. Examples of initiators for stereoselective ROMP reactions.

It occurred to us that post-polymerization modification (PPM) of backbone $\mathrm{C}=\mathrm{C}$ bonds might be a valuable approach for identifying the tacticity of a stereoregular polymer prepared from an chiral monomer through ROMP methods. We devised two PPM approaches for proving the tacticity of stereoregular polymers prepared from NBE, TCD, and 3-methyl-3phenylcyclopropene (MPCP). We found that the tacticities of all three polymers could be proven and are in agreement with predictions. 


\section{RESULTS AND DISCUSSION}

The first two requirements for a tacticity proof employing a PPM method are that the polymer be essentially a single structure and that the PPM method be strictly stereospecific. Bromination and epoxidation are examples of stereospecific reactions at $\mathrm{C}=\mathrm{C}$ bonds that proceed in strictly an anti and syn manner, respectively. Other requirements for a successful identification of tacticity of a stereoregular polymer include (i) modification of only a small percentage of $\mathrm{C}=\mathrm{C}$ bonds in order that the resulting modified double bond remains in a homogeneous polymer environment; (ii) being able to observe (through proton NMR methods) the small percentage of protons in the modified polymer; (iii) compatibility of the PPM method with any functionality that is present; (iv) stabilitity of the modified polymer; and (v) sufficient solubility of the polymer for NMR studies. Although failure of one or more of these five requirements has limited the generality of the PPM approach for determining the structure of all stereoregular polymers that we have tried, we have proven that both bromination and epoxidation are successful methods for a selected number of polymers. These methods therefore are potentially applicable to determination of tacticity in other stereoregular polymers prepared through ROMP.

\section{Bromination of poly(norbornene)}

Bromine addition to a $\mathrm{C}=\mathrm{C}$ double bond proceeds in an anti fashion. All possible structures that can be made through bromine addition to cis,tactic and trans,tactic poly(NBE) $(\mathrm{NBE}=$ norbornene $)$ are depicted in Schemes 1 and 2, respectively. Protons $\mathrm{H}_{\mathrm{A}}$ and $\mathrm{H}_{\mathrm{B}}$ in the

resulting $\mathrm{BrCHCHBr}$ unit(s) are inequivalent and therefore distinguishable by ${ }^{1} \mathrm{H}$ NMR methods. Bromine addition to cis, isotactic poly(NBE) and trans,syndiotactic-poly(NBE) generates protons $\mathrm{H}\left(1^{\prime}, 6^{\prime}\right)_{\mathrm{A}}$ and $\mathrm{H}\left(1^{\prime}, 6^{\prime}\right)_{\mathrm{B}}$, that are coupled to each other. If their chemical shifts are sufficiently different, it could be shown that they are correlated in a ${ }^{1} \mathrm{H},{ }^{1} \mathrm{H}$ gCOSY experiment. Bromine addition to cis,syndiotactic poly(NBE) and trans, isotactic poly(NBE) generates protons $\mathrm{H}\left(1^{\prime}, 6^{\prime}\right)_{\mathrm{A}}$ and $\mathrm{H}\left(1^{\prime}, 6^{\prime}\right)_{\mathrm{B}}$ in different $\mathrm{BrCHCHBr}$ units that should not be correlated in a ${ }^{1} \mathrm{H}-{ }^{1} \mathrm{H}$ gCOSY experiment. Therefore, if the polymer is stereoregular and it can be determined whether it is all cis or all trans through IR studies, and the requirements stated in the above paragraph are all satisfied, then it may be possible to determine the tacticity through bromination. If two stereoregular polymers both have either a cis or trans stereochemistry it is necessary only to prove the tacticity of one in order to prove them both. 

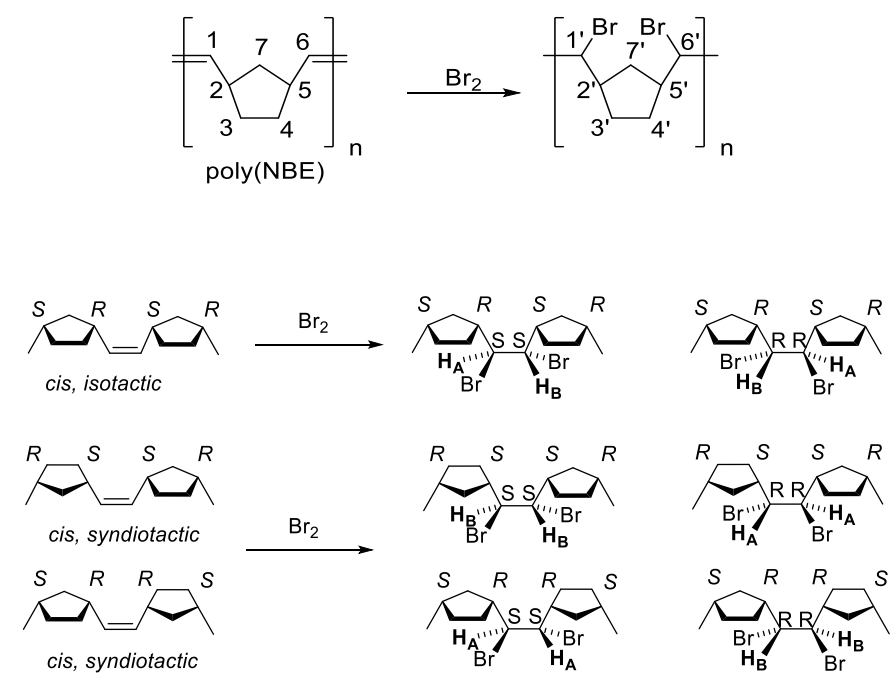

Scheme 1. Bromination of backbone double bonds in cis, isotactic-poly(NBE) and cis,syndiotactic-poly(NBE).

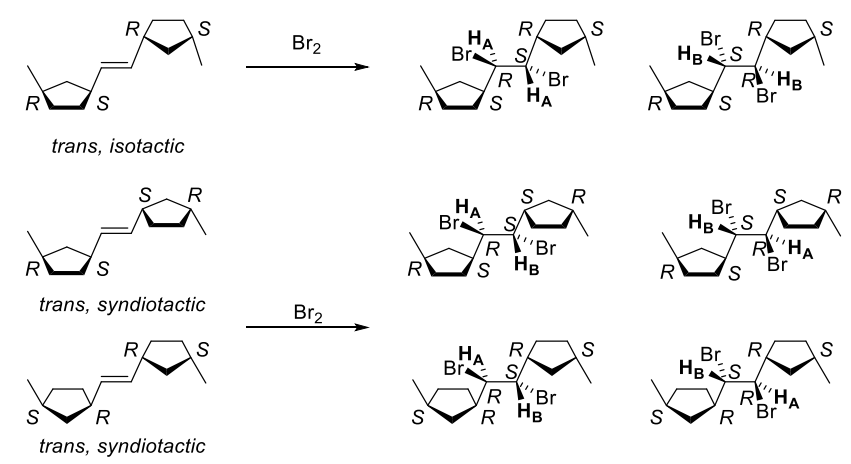

Scheme 2. Bromination of backbone double bonds in trans, isotactic-poly(NBE) and trans,syndiotactic-poly(NBE).

Only recently has it been shown that both cis,syndiotactic-poly(NBE) and cis,isotacticpoly(NBE) samples ${ }^{5}$ can be prepared and can be distinguished from one another through NMR methods. Samples of each polynorbornene were brominated to an extent of $\sim 3 \%$ through dropwise addition of a solution of bromine in $0.5 \mathrm{~mL}$ of $\mathrm{CDCl}_{3}$ to a stirred solution of polymer (20 mg, $0.212 \mathrm{mmol}$ ) in $0.8 \mathrm{~mL}$ of $\mathrm{CDCl}_{3}$. Slow addition of bromine to a rapidly stirred solution produced polymers with the sharpest NMR spectra, probably because $\mathrm{BrCHCHBr}$ units are then essentially isolated throughout the stereoregular polymer. Proton NMR analyses of all samples were undertaken without further workup. 


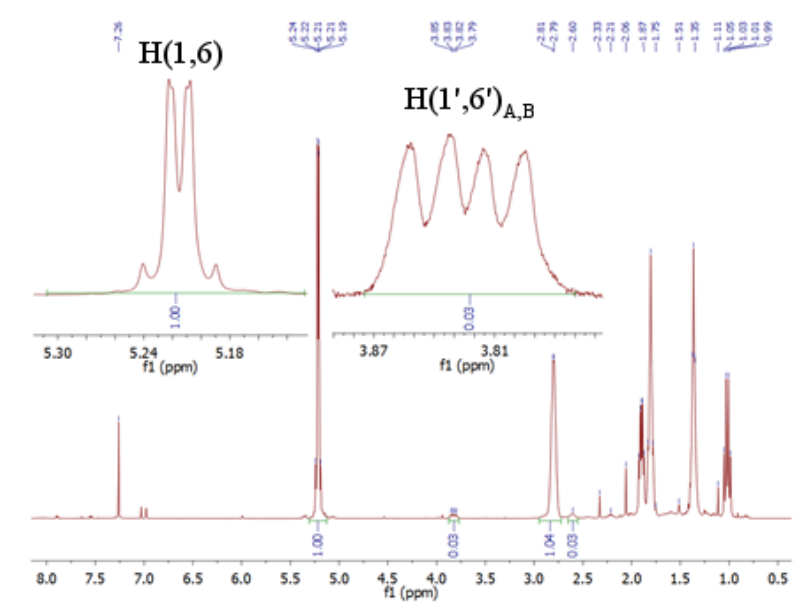

Figure 3. ${ }^{1} \mathrm{H}$ NMR spectrum of partially brominated (3\% conversion) cis,syndiotactic poly(NBE).

In the case of bromination of cis,syndiotactic-poly(NBE), doublets for $\mathrm{H}\left(1^{\prime}, 6^{\prime}\right)_{\mathrm{A}}\left(J_{I^{\prime}, 2^{\prime}}=\right.$ $10.0 \mathrm{~Hz})$ at $3.84 \mathrm{ppm}$ and $\mathrm{H}\left(1^{\prime}, 6^{\prime}\right)_{\mathrm{B}}\left(J_{1^{\prime}, 2^{\prime}}=9.9 \mathrm{~Hz}\right)$ at $3.81 \mathrm{ppm}$ were found in the area typical for $\alpha$-hydrogens in bromoalkanes (near $3.83 \mathrm{ppm}$, Figure 3). The resonance at $2.60 \mathrm{ppm}$ is assigned to the methine protons $\mathrm{H}\left(2^{\prime}, 5^{\prime}\right)$ in the brominated double bonds. When the resonance for protons $\mathrm{H}\left(2^{\prime}, 5^{\prime}\right)$ was irradiated, singlets were observed for $\mathrm{H}\left(1^{\prime}, 6^{\prime}\right)_{\mathrm{A}}$ at $3.84 \mathrm{ppm}$ and $\mathrm{H}\left(1^{\prime}, 6^{\prime}\right)_{\mathrm{B}}$ at 3.81 ppm (Figure 4). The ${ }^{1} \mathrm{H},{ }^{1} \mathrm{H}$ gCOSY showed that $\mathrm{H}\left(1^{\prime}, 6^{\prime}\right)_{\mathrm{A}}$ and $\mathrm{H}\left(1^{\prime}, 6^{\prime}\right)_{\mathrm{B}}$ are not coupled (Figures S1-S2). Therefore, these experiments prove that the structure prior to bromination is cis,syndiotactic (Scheme 1), as proposed.

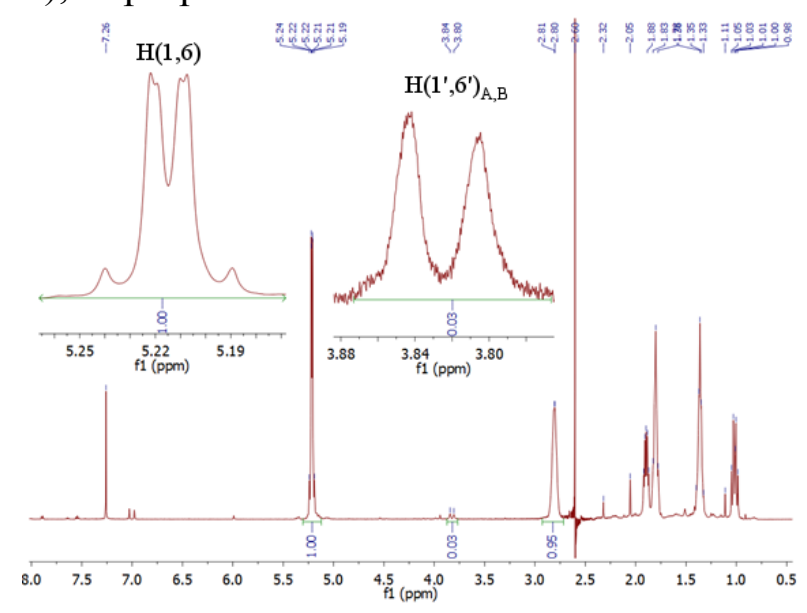

Figure 4. ${ }^{1} \mathrm{H}$ NMR spectrum of partially brominated ( $3 \%$ conversion) cis,syndiotactic poly(NBE) with decoupling of the methine protons $\mathrm{H}\left(2^{\prime}, 5^{\prime}\right)$ at $2.60 \mathrm{ppm}$.

The proton NMR spectrum of partially brominated cis, isotactic-poly(NBE) revealed a broad doublet corresponding to the $\mathrm{H}\left(1^{\prime}, 6^{\prime}\right)_{\mathrm{A}}$ and $\mathrm{H}\left(1^{\prime}, 6^{\prime}\right)_{B}$ protons at $3.83 \mathrm{ppm}$. Selective 
decoupling of the methine protons $\mathrm{H}\left(2^{\prime}, 5^{\prime}\right)$ at $2.60 \mathrm{ppm}$ did not yield a significantly more resolved spectrum (see the SI, Figures S3 and S4), nor did spectra at several other temperatures. Therefore, this bromination is inconclusive. However, a proof of the cis,isotactic structure would be redundant since the cis,syndiotactic structure has been proven.

\section{Epoxidation of poly(3-methyl-3-phenylcyclopropene) (MPCP)}

3-Methyl-3-phenylcyclopropene (MPCP) has been polymerized with initiators of the type $\mathrm{Mo}(\mathrm{NAd})\left(\mathrm{CHCMe}_{2} \mathrm{Ph}\right)($ pyrrolide$)(\mathrm{OHIPT})\left(\mathrm{Ad}=1\right.$-adamantyl, OHIPT $\left.=2,6-\mathrm{Mesityl}_{2} \mathrm{C}_{6} \mathrm{H}_{3}\right)$ to give what was proposed to be cis,syndiotactic-poly(MPCP), ${ }^{8 \mathrm{~d}}$ while what has been proposed to be cis,isotactic-poly(MPCP) $)^{10}$ has been prepared with initiators of the type $\mathrm{Mo}(\mathrm{NAr})\left(\mathrm{CHCMe}_{2} \mathrm{Ph}\right)($ biphenolate $)\left(\mathrm{Ar}=2,6-i-\mathrm{Pr}_{2} \mathrm{C}_{6} \mathrm{H}_{3}\right)$. On the basis of an absence of a relatively intense IR peak in the region $970-980 \mathrm{~cm}^{-1}$ a cis configuration was assigned to these two stereoregular polymers. ${ }^{8 \mathrm{~d}}$

All possible structures of partially epoxidized cis,tactic-poly(MPCP) (MPCP = methylphenylcyclopropene) are shown in Scheme 3. Epoxidation of cis,syndiotacticpoly(MPCP) should generate an epoxide with two inequivalent protons, $\mathrm{H}\left(1^{\prime}, 10^{\prime}\right)_{\mathrm{A}}$ and $\mathrm{H}\left(1^{\prime}, 10^{\prime}\right)_{\mathrm{B}}$, that are coupled to each other, while epoxidation of cis, isotactic-poly(MPCP) should generate protons, $\mathrm{H}\left(1^{\prime}, 10^{\prime}\right)_{\mathrm{A}}$ and $\mathrm{H}\left(1^{\prime}, 10^{\prime}\right)_{\mathrm{B}}$, that are in different epoxides. Because the two $\mathrm{C}=\mathrm{C}$ faces are different in cis,isotactic-poly(MPCP), the two inequivalent protons are not likely to be found in a ratio of $1: 1$.
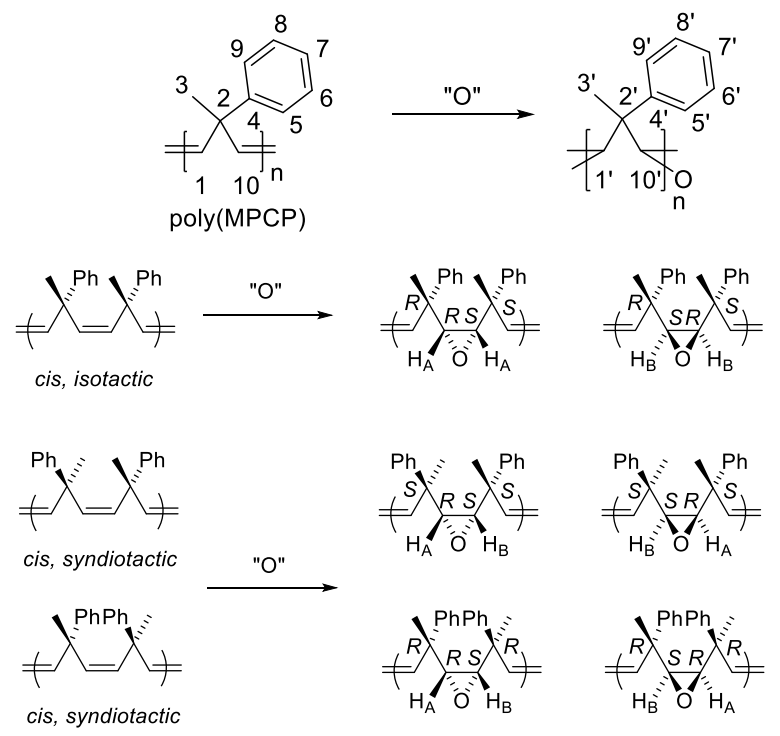

Scheme 3. Epoxidation of the backbone double bonds in cis, isotactic and cis, syndiotactic poly(MPCP). 


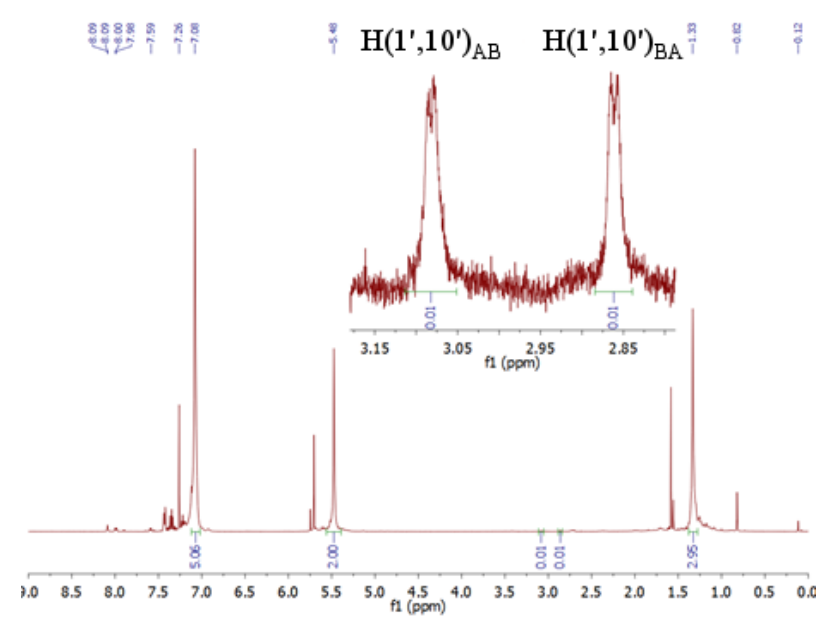

Figure 5. ${ }^{1} \mathrm{H}$ NMR spectrum of lightly epoxidized ( 1\%) cis,syndiotactic-poly(MPCP).

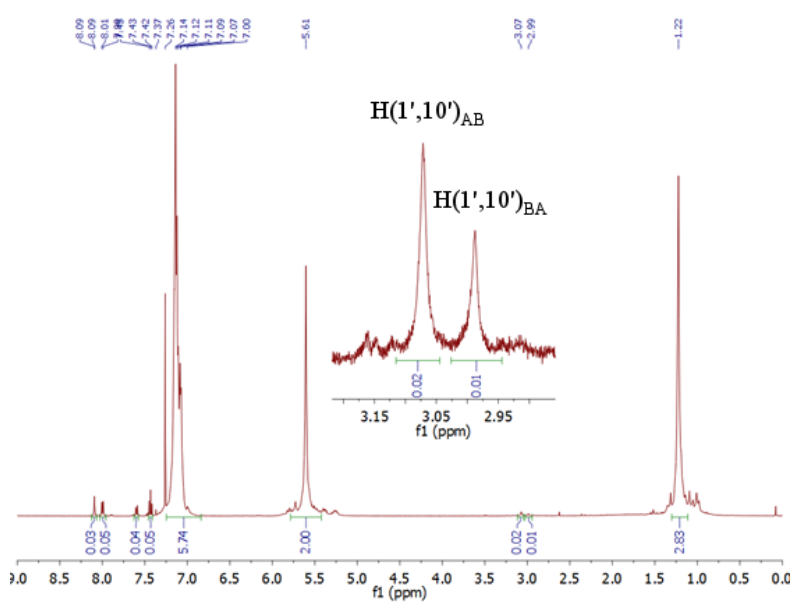

Figure 6. ${ }^{1} \mathrm{H}$ NMR spectrum of lightly epoxidized ( 1.5\%) cis, isotactic-poly(MPCP).

Stereoregular cis-poly(MPCP) samples were epoxidized to the extent of $\sim 1 \%$ through addition of $m$-CPBA ( $m$-chloroperoxybenzoic acid) to the solution of polymer $(10 \mathrm{mg}, 0.077$ $\mathrm{mmol}$ ) in $1.0 \mathrm{~mL}$ of $\mathrm{CDCl}_{3}$. Resolution of the epoxide protons in ${ }^{1} \mathrm{H}$ NMR spectra was less satisfactory in samples with $>1 \%$ epoxidation. All samples were stirred for fourteen hours and examined without further workup. In the proton NMR spectrum of the epoxidized cis,syndiotactic-poly(MPCP) doublets were observed for $\mathrm{H}\left(1^{\prime}, 10^{\prime}\right)_{\mathrm{A}}\left(J_{A B}=4.0 \mathrm{~Hz}\right)$ at $3.09 \mathrm{ppm}$ and $\mathrm{H}\left(1^{\prime}, 10^{\prime}\right)_{\mathrm{B}}\left(J_{A B}=4.0 \mathrm{~Hz}\right)$ at $2.86 \mathrm{ppm}$, the region typical for $\alpha$-hydrogens in epoxides (Figure 5); the two protons are coupled by $4.0 \mathrm{~Hz}$, as confirmed in a ${ }^{1} \mathrm{H},{ }^{1} \mathrm{H}$ gCOSY spectrum (Figures S5 and S6 in SI). These results prove that the polymer is cis,syndiotactic-poly(MPCP), as proposed.

In the proton NMR spectrum of $\sim 1.5 \%$ epoxidized cis, isotactic-poly(MPCP) two singlets, 
$\mathrm{H}\left(1^{\prime}, 10^{\prime}\right)_{\mathrm{A}}$ at $3.09 \mathrm{ppm}$ and $\mathrm{H}\left(1^{\prime}, 10^{\prime}\right)_{\mathrm{B}}$ at $2.86 \mathrm{ppm}$ in a ratio of approximately $2: 1$, were found in the region typical for $\alpha$-hydrogens of the epoxide ring (Figure 6). A ${ }^{1} \mathrm{H},{ }^{1} \mathrm{H}$ gCOSY spectrum showed that these two protons are not coupled (Figures S7 and S8 in SI). These results prove that the sample is cis,isotactic-poly(MPCP), as proposed. Being able to prove both the cis,syndiotactic and cis, isotactic structures of poly(MPCP) is satisfying, although a proof of both is again redundant.

\section{Epoxidation of poly(endo,anti-tetracyclododecene)}

Like norbornene, endo,anti-tetracyclododecene (TCD) has been polymerized stereoselectively to give what are proposed to be cis,syndiotactic-poly(TCD) and cis,isotacticpoly(TCD). ${ }^{5}$ All possible structures of epoxidized $\mathrm{C}=\mathrm{C}$ bonds of cis,tactic-poly(TCD) are shown in Scheme 4. Epoxidation of cis,syndiotactic-poly(TCD) generates an epoxide with two inequivalent protons, $\mathrm{H}\left(1^{\prime}, 6^{\prime}\right)_{\mathrm{A}}$ and $\mathrm{H}\left(1^{\prime}, 6^{\prime}\right)_{\mathrm{B}}$, that are coupled to each other, while epoxidation of cis,isotactic-poly(TCD) generates different epoxides with equivalent protons, $\mathrm{H}\left(1^{\prime}, 6^{\prime}\right)_{\mathrm{A}}$ and $\mathrm{H}\left(1^{\prime}, 6^{\prime}\right)_{\mathrm{B}}$. The epoxidation reactions were performed in a manner analogous to the epoxidation of poly(MPCP) (vide supra).

Evaluation of proton NMR spectra of the lightly epoxidized samples of poly(TCD) is complicated by significant overlap of the proton resonances of interest $\left(\mathrm{H}\left(1^{\prime}, 6^{\prime}\right)\right)$ in the epoxide with protons $\mathrm{H}(2,5)$ (at $2.95 \mathrm{ppm}$, Figure 7). Although the analysis consequently is not as convincing as that for the partially epoxidized poly(MPCP) above, the data for poly(MPCP) helps convince us that the analysis for poly(TCD) is correct. Overlap of resonances is one typical complication in the use of PPM as a general method for analyzing tacticity of ROMP polymers.

The proton NMR sample of partially epoxidized cis,syndiotactic-poly(TCD) (7\%) revealed two multiplets, $\mathrm{H}\left(1^{\prime}, 6^{\prime}\right)_{\mathrm{A}}$ at $3.05 \mathrm{ppm}$ and $\mathrm{H}\left(1^{\prime}, 6^{\prime}\right)_{\mathrm{B}}$ at $3.00 \mathrm{ppm}$ in the region typical for $\alpha$-hydrogen chemical shifts of epoxide protons (Figure 7). Selective decoupling of the methine protons $\mathrm{H}\left(2^{\prime}, 5^{\prime}\right)$ at $1.90 \mathrm{ppm}$ afforded two broad multiplets for $\mathrm{H}\left(1^{\prime}, 6^{\prime}\right)_{\mathrm{A}}$ and $\mathrm{H}\left(1^{\prime}, 6^{\prime}\right)_{\mathrm{B}}$ (Figure 8);

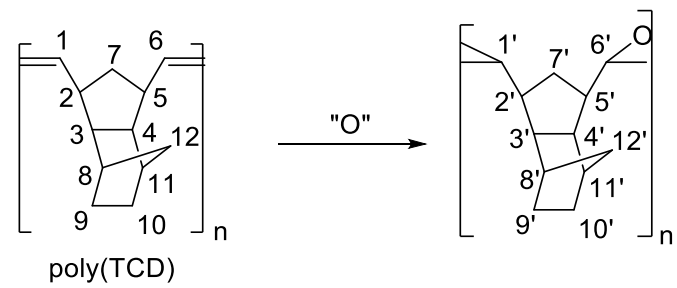




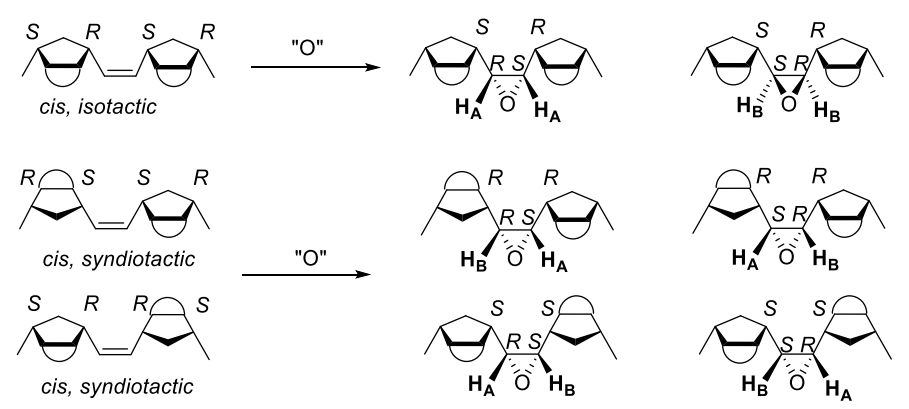

Scheme 4. Epoxidation of backbone double bonds in cis, isotactic and cis, syndiotactic poly(TCD).

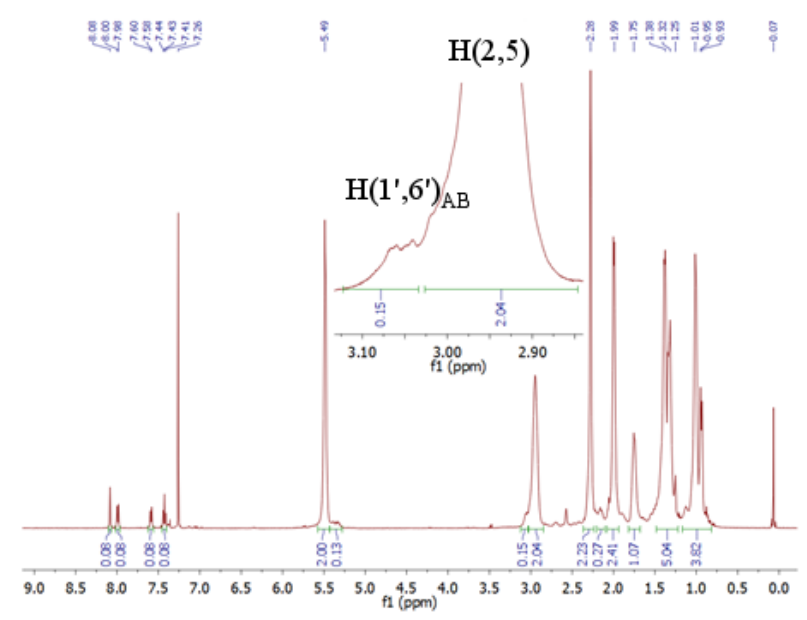

Figure 7. The ${ }^{1} \mathrm{H}$ NMR spectrum of epoxidized (7\%) cis,syndiotactic-poly(TCD).

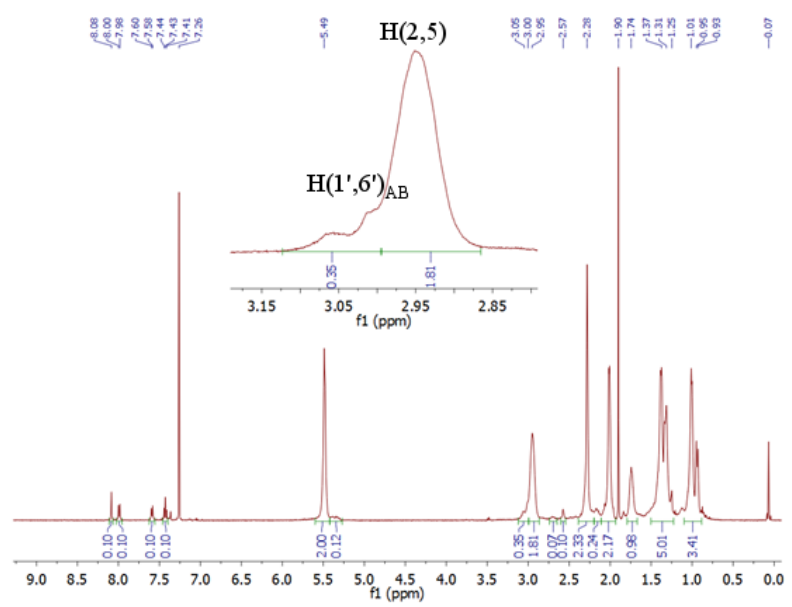

Figure 8. The ${ }^{1} \mathrm{H}$ NMR spectrum of epoxidized (7\%) cis,syndiotactic-poly(TCD) with selective decoupling of the methine protons at $1.90 \mathrm{ppm}$. 


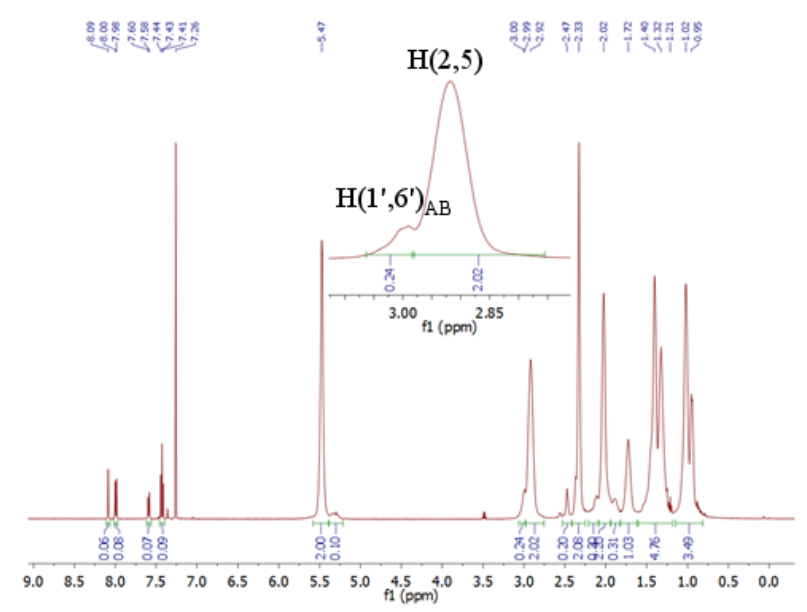

Figure 9. ${ }^{1} \mathrm{H}$ NMR spectrum of epoxidized (11\%) cis, isotactic-poly(TCD).

a ${ }^{1} \mathrm{H},{ }^{1} \mathrm{H}$ gCOSY spectrum showed them to be coupled (Figures S9 and S10 in SI). Therefore, the structure of cis,syndiotactic-poly(TCD) is proven.

The proton NMR sample of partially epoxidized cis,isotactic-poly(TCD) (11\%) revealed two multiplets, $\mathrm{H}\left(1^{\prime}, 6^{\prime}\right) \mathrm{A}$ at $3.04 \mathrm{ppm}$ and $\mathrm{H}\left(1^{\prime}, 6^{\prime}\right) \mathrm{B}$ at $3.00 \mathrm{ppm}$, which are in the region typical for $\alpha$-protons in epoxides (Figure 9). Selective decoupling of the methine protons $H\left(2^{\prime}, 5^{\prime}\right)$ at 1.89 ppm led to two broad multiplets for $\mathrm{H}\left(1^{\prime}, 6^{\prime}\right) \mathrm{A}$ and $\mathrm{H}\left(1^{\prime}, 6^{\prime}\right) \mathrm{B}$ (Figure 10); a 1H,1H gCOSY spectrum showed that protons A and B were not coupled to each other (Figures S11 and S12 in $\mathrm{SI})$. Therefore, the structure of cis, isotactic-poly(TCD) is proven.

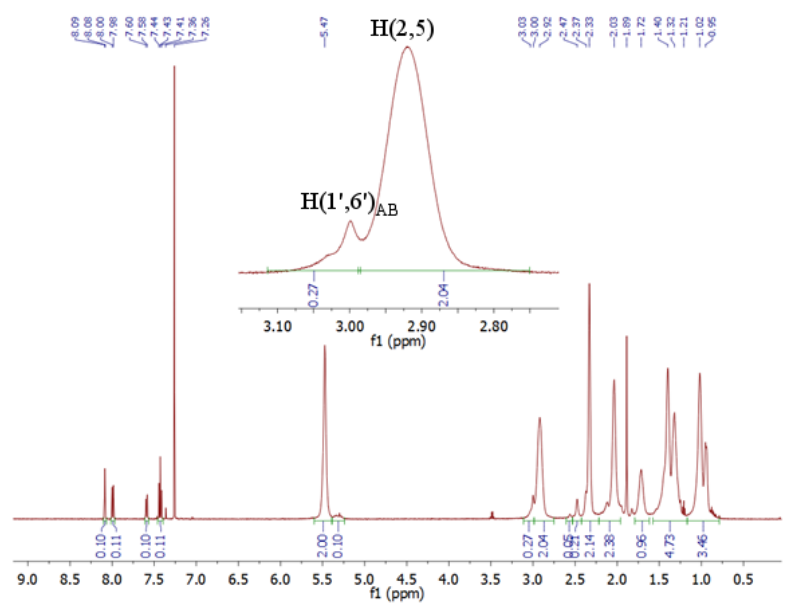

Figure 10. ${ }^{1} \mathrm{H}$ NMR spectrum of epoxidized (11\%) cis, isotactic-poly(TCD) with selective decoupling of methine proton $\mathrm{H}\left(2^{\prime}, 5^{\prime}\right)$ at $1.89 \mathrm{ppm}$. 


\section{CONCLUSIONS}

The tacticities of three cis, tactic polymers made with well-defined initiators (1 and 2$)$ that have been proposed to give cis,isotactic and cis,syndiotactic polymers from achiral monomers have been proven through post polymerization modification. The two methods, bromination and epoxidation, are complementary. Although we have found that each method has its limitations, depending upon circumstances, as outlined in the beginning of this paper, each should prove useful as a means of determining tacticities of some stereoregular cis polymers prepared through ROMP. These methods should also allow the tacticities of trans, highly tactic polymers, to be determined, although pure trans, tactic polymers currently cannot be prepared through reliable methods. ${ }^{2}$

Acknowledgments. We are grateful to the Department of Energy (DE-FG02-86ER13564) for research support. J. H. thanks the Experientia Foundation for a one year postdoctoral fellowship.

Supporting Information Available. Experimental details for the synthesis of various polymers and NMR spectra of all polymers. This material is available free of charge via the Internet at http://pubs.acs.org.

\section{References}

${ }^{1}$ (a) Ivin, K. J.; Mol, J. C. Olefin Metathesis and Metathesis Polymerization; Academic Press: San Diego, 1997. (b) Ivin. K. J. Olefin Metathesis; Academic Press: San Diego, 1983. (c) Buchmeiser, M. R. Chem. Rev. 2000, 100, 1565. (d) Bielawski, C. W.; Grubbs, R. H. Prog. Poly. Sci. 2007, 32, 1. (e) Smith, E.; Pentzer, E. B.; Nguyen, S. T. Polym. Rev. 2007, 47, 419. (f) Buchmeiser, M. R. Chem. Rev. 2009, 109, 303. (g) Grubbs, R. H., Ed., Handbook of Metathesis; Wiley-VCH: Weinheim, 2003; Vols. 1 and 2.

2 (a) Schrock, R. R. Dalton Trans. 2011, 40, 7484. (b) Schrock, R. R. Acc. Chem. Res. 2014, 47, 2457.

${ }^{3}$ O’Dell, R.; McConville, D. H.; Hofmeister, G. E.; Schrock, R. R. J. Am. Chem. Soc., 1994, 116,3414 .

${ }^{4}$ Forrest, W. P.; Weis, J. G.; John, J. M.; Axtell, J. C.; Simpson, J. H.; Swager, T. M.; Schrock, R. R. J. Am. Chem. Soc. 2014, 136, 10910.

${ }^{5}$ Autenrieth, B.; Schrock, R. R. Macromolecules 2015, asap April 7, 10.1021/acs.macromol.5b00161. 
${ }^{6}$ Autenrieth, B.; Jeong, H.; Forrest, W. P.; Axtell, J. C.; Ota, A.; Lehr, T.; Buchmeiser, M. R.; Schrock, R. R. Macromolecules 2015, in press.

${ }^{7}$ Jeong, H.; Ng, V. W. L.; Börner, J.; Schrock, R. R. Macromolecules 2015, asap March 17, DOI 10.1021/acs.macromol.5b00264.

${ }^{8}$ (a) Flook, M. M.; Jiang, A. J.; Schrock, R. R.; Müller, P.; Hoveyda, A. H. J. Am. Chem. Soc. 2009, 131, 7962. (b) Jeong, H.; Kozera, D. J.; Schrock, R. R.; Smith, S. J.; Zhang, J.; Ren, N.; Hillmyer, M. A. Organometallics 2013, 32, 4843. (c) Flook, M. M.; Börner, J.; Kilyanek, S.; Gerber, L. C. H.; Schrock, R. R. Organometallics 2012, 31, 6231. (d) Flook, M. M.; Gerber, L. C. H.; Debelouchina, G. T.; Schrock, R. R. Macromolecules 2010, 43, 7515. (e) Flook, M. M.; Ng, V. W. L.; Schrock, R. R. J. Am. Chem. Soc. 2011, 133, 1784. (f) Forrest, W. P.; Axtell, J. C.; Schrock, R. R. Organometallics 2014, 33, 2313.

9 (a) Hayano, S.; Nakama, Y. Macromolecules 2014, 47, 7797. (b) Hayano, S.; Kurakata, H.; Tsunogae, Y.; Nakayama, Y.; Sato, Y.; Yasuda, H. Macromolecules 2003, 36, 7422.

${ }^{10}$ Singh, R.; Schrock, R. R. Macromolecules 2008, 41, 2990. 
TOC for

\section{Proof of Tacticity of Stereoregular ROMP Polymers Through Post Polymerization Modification}

Jakub Hyvl, Benjamin Autenrieth, and Richard R. Schrock*

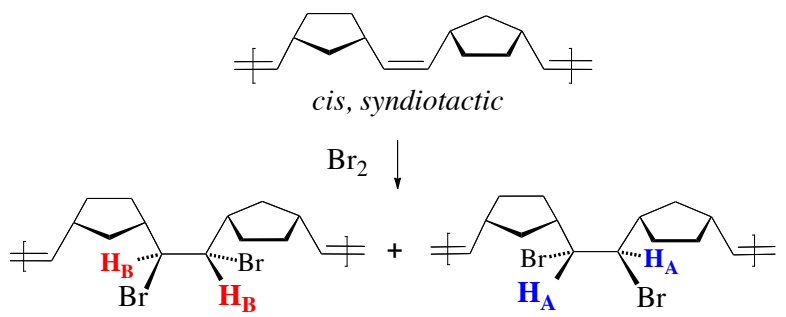


Supporting Information for

\title{
Proof of Tacticity of Stereoregular ROMP Polymers Through Post Polymerization Modification
}

\author{
Jakub Hyvl, Benjamin Autenrieth, and Richard R. Schrock* \\ Department of Chemistry 6-331, Massachusetts Institute of Technology, Cambridge, \\ Massachusetts 02139
}




\title{
Contents
}

1. Abbreviations (page S2)

2. General comments on Experimental Section (page S2)

3. $\quad{ }^{1} \mathrm{H}$ NMR and ${ }^{1} \mathrm{H},{ }^{1} \mathrm{H}$ gCOSY spectra of the modified polymers (pages S3-S13)

4. References (pages S13)

\author{
Abbreviations \\ m-CPBA: $m$-chloroperbenzoic acid \\ poly(NBE): poly(norbornene) \\ poly(TCD): poly(tetracyclododecene) \\ poly(MPCP): poly(methylphenylcyclopropene)
}

\section{General Comments on Experimental Section}

Chloroform- $d$ was stored over molecular sieves. The following chemicals were purchased from Aldrich and used as received: bromine and m-CPBA. The following substances were prepared according to literature procedures: cis,syndiotactic poly(NBE), ${ }^{1}$ cis, isotactic poly(NBE), ${ }^{1} \quad$ cis,syndiotactic $\quad$ poly(TCD),${ }^{1} \quad$ cis, isotactic $\quad$ poly(TCD), ${ }^{1} \quad$ cis, $\quad$ isotactic poly(MPCP $)^{2}$ and cis, syndiotactic poly(MPCP). ${ }^{3}$ Cis, isotactic polymers were prepared from 1, cis,syndiotactic from 2. The catalyst to monomer ratio was $1: 100$ at $22{ }^{\circ} \mathrm{C}$ in dichloromethane. NMR spectra were recorded on $500 \mathrm{MHz}$ spectrometers. NMR chemical shifts are reported as ppm relative to tetramethylsilane, and are referenced to the residual proton of the solvent $\left({ }^{1} \mathrm{H} \mathrm{CDCl}_{3}: 7.26 \mathrm{ppm}\right)$.

\section{Representative procedure for epoxidation}

$m$-CPBA ( $m$-chloroperoxybenzoic acid) ( $1 \mathrm{mg}$, declared purity is 77\%, $4.5 \mu \mathrm{mol})$ was added at once to a stirred solution of cis,syndiotactic-poly(MPCP) $(10 \mathrm{mg}, 0.077 \mathrm{mmol})$ in $1.0 \mathrm{~mL}$ of $\mathrm{CDCl}_{3}$. The sample was stirred at RT for $17 \mathrm{~h}$ and analyzed without further workup.

\section{Representative procedure for bromination}

A solution of bromine $(1.0 \mathrm{mg}, 6.0 \mu \mathrm{mol})$ in $0.5 \mathrm{~mL}$ of $\mathrm{CDCl}_{3}$ was added dropwise to a stirred solution of cis,syndiotactic-poly(NBE) $(20 \mathrm{mg}, 0.212 \mathrm{mmol})$ in $0.8 \mathrm{~mL}$ of $\mathrm{CDCl}_{3}$. Slow addition of bromine solution to a rapidly stirred polymer solution is essential for obtaining of homogenous sample. The sample was analyzed without further workup. 


\section{Bromination of poly(norbornene)}

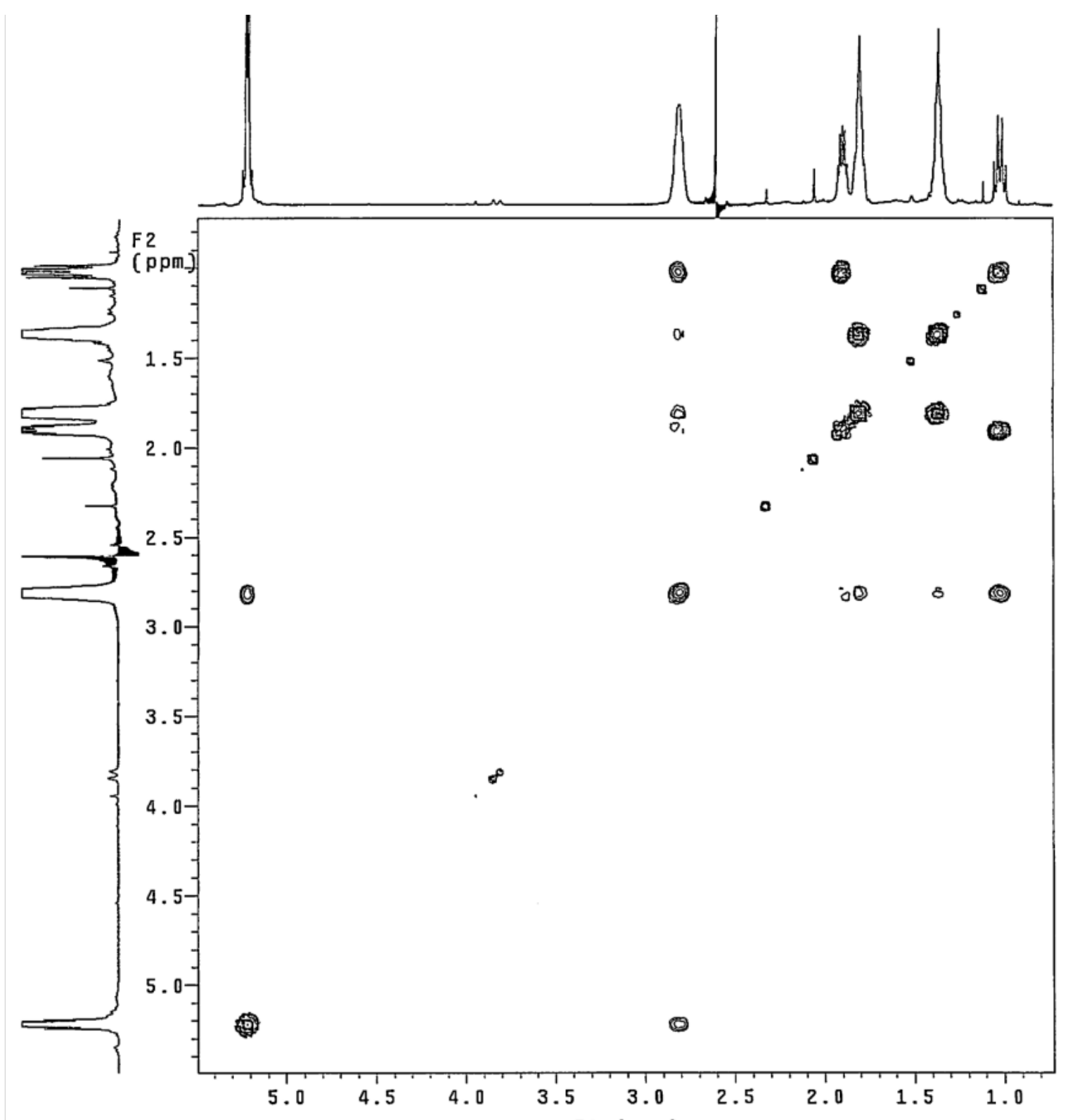

Figure S1. ${ }^{1} \mathrm{H},{ }^{1} \mathrm{H}$ gCOSY spectrum of partially brominated (3\%) cis, syndiotactic poly(NBE) with decoupling of the methine proton $\mathrm{H}\left(2^{\prime}, 5^{\prime}\right)$ at $2.60 \mathrm{ppm}$. 


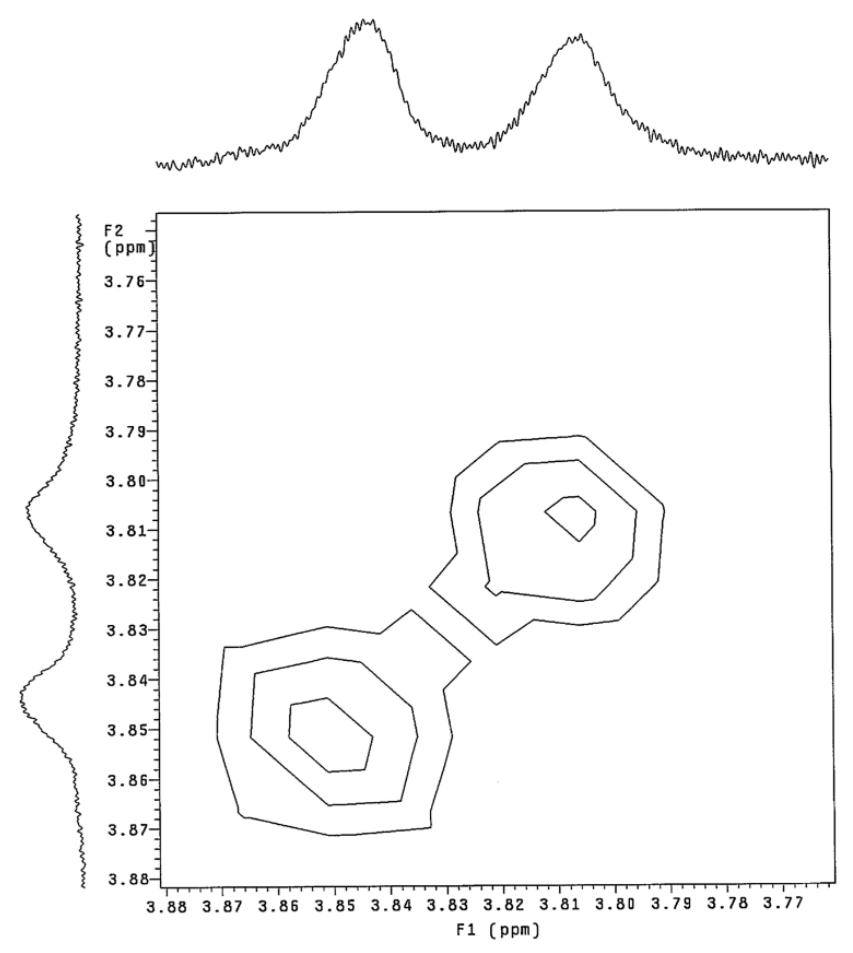

Figure S2. $\mathrm{H}\left(1^{\prime}, 6^{\prime}\right)_{\mathrm{A}}$ and $\mathrm{H}\left(1^{\prime}, 6^{\prime}\right)_{\mathrm{B}}$ protons in ${ }^{1} \mathrm{H},{ }^{1} \mathrm{H}$ gCOSY spectrum of partially brominated (3\%) cis, syndiotactic poly(NBE) with decoupling of the methine proton $\mathrm{H}\left(2^{\prime}, 5^{\prime}\right)$ at $2.60 \mathrm{ppm}$.

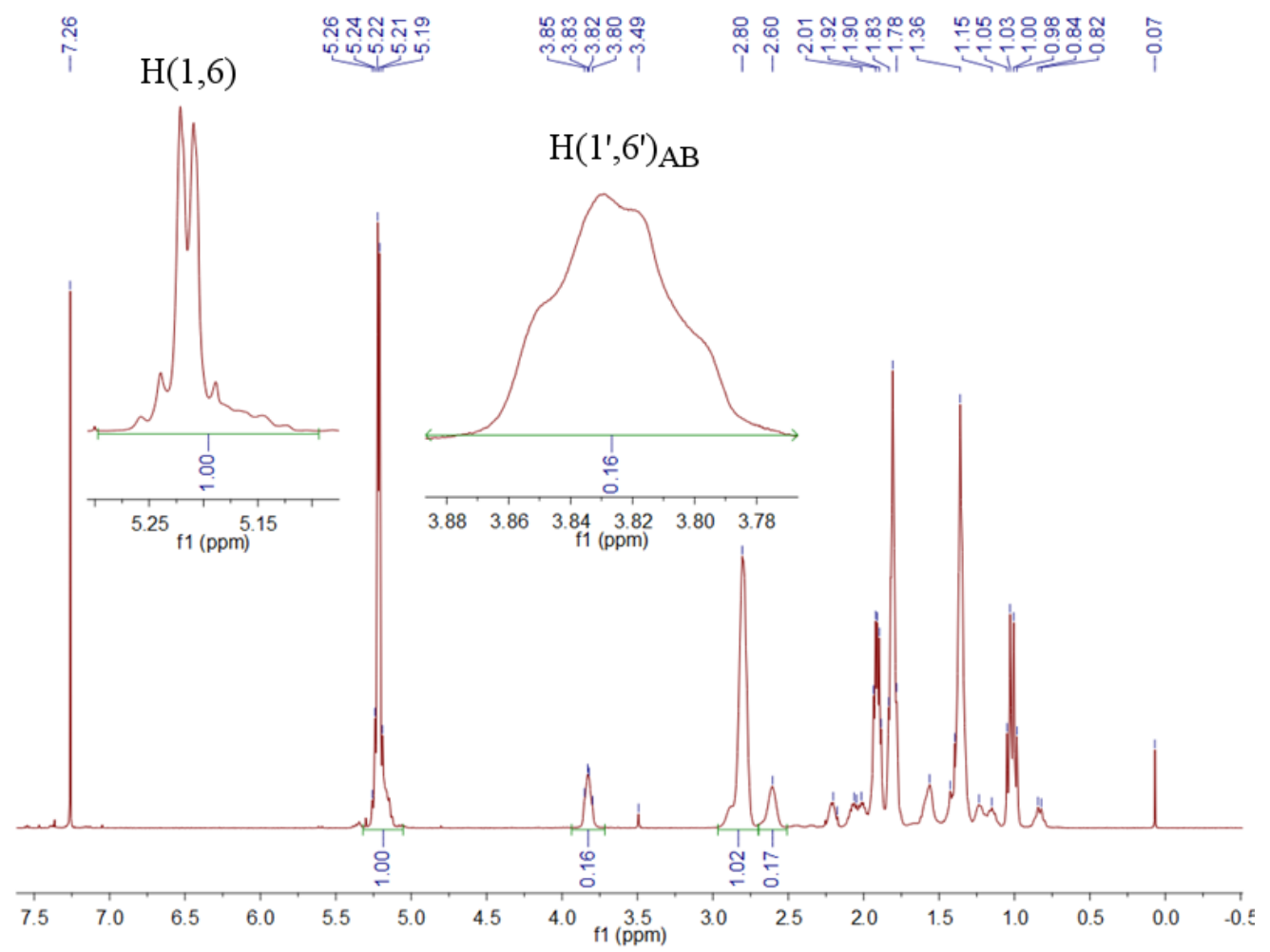

Figure S3. ${ }^{1} \mathrm{H}$ NMR spectrum of partially brominated (14\% conversion) cis, isotactic poly(NBE). 


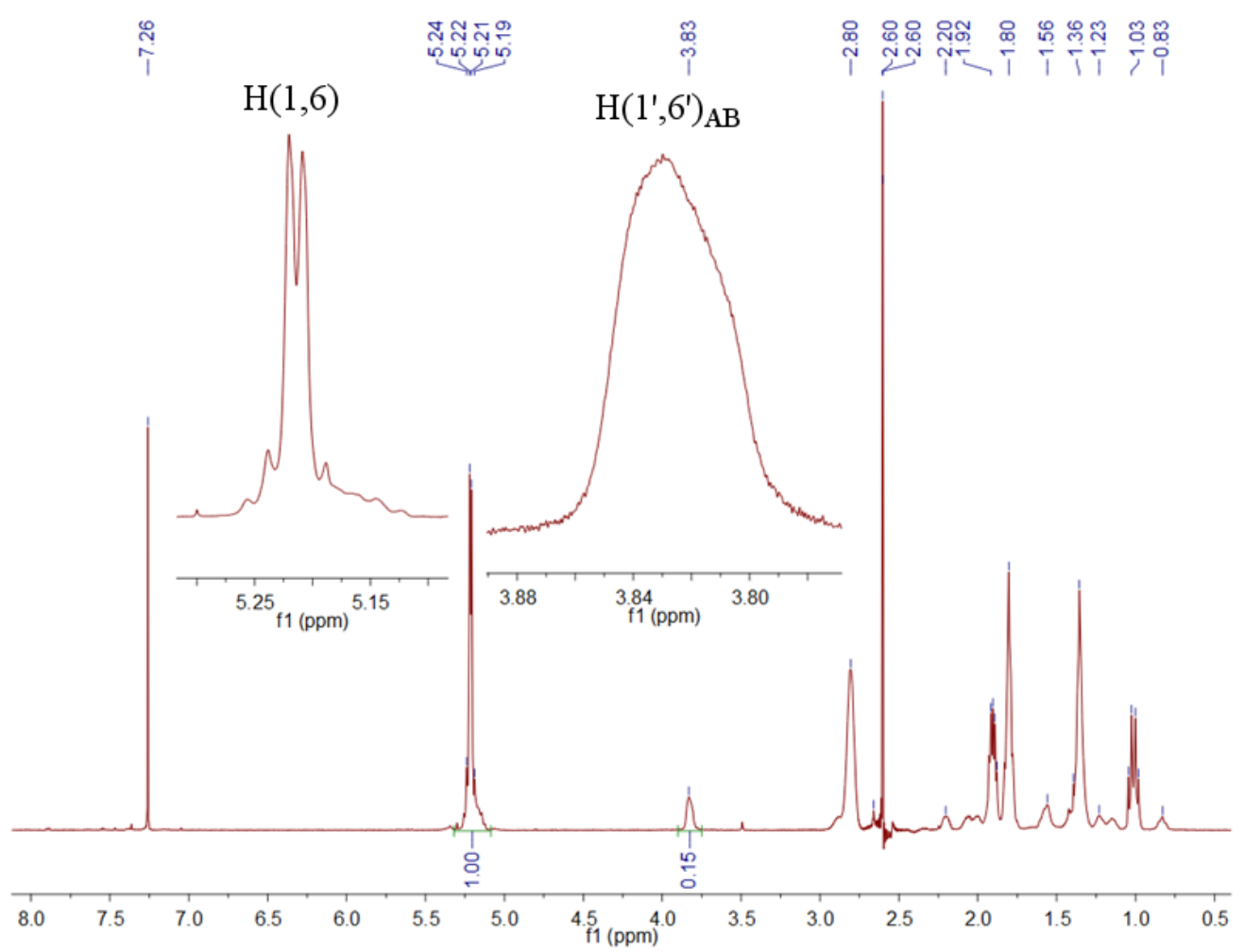

Figure S4. ${ }^{1} \mathrm{H}$ NMR spectrum of partially brominated (14\% conversion) cis, isotactic poly(NBE) with decoupling of the methine proton $\mathrm{H}\left(2^{\prime}, 5^{\prime}\right)$ at $2.60 \mathrm{ppm}$. 
Epoxidation of poly(3-methyl-3-phenylcyclopropene) (MPCP)

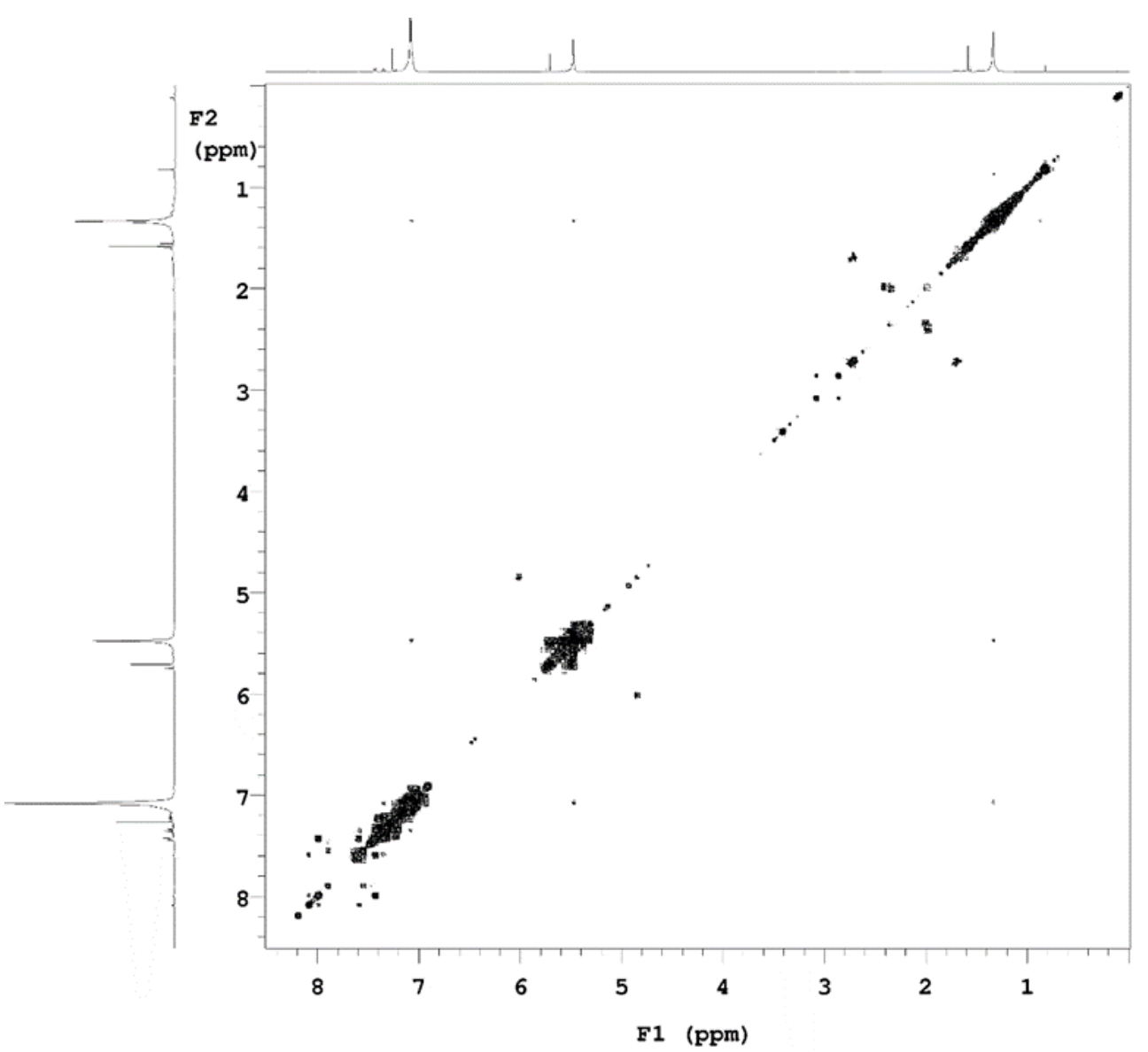

Figure S5. ${ }^{1} \mathrm{H},{ }^{1} \mathrm{H}$ gCOSY spectrum of partially epoxidated (1\% conversion) cis, syndiotactic poly(MPCP). 


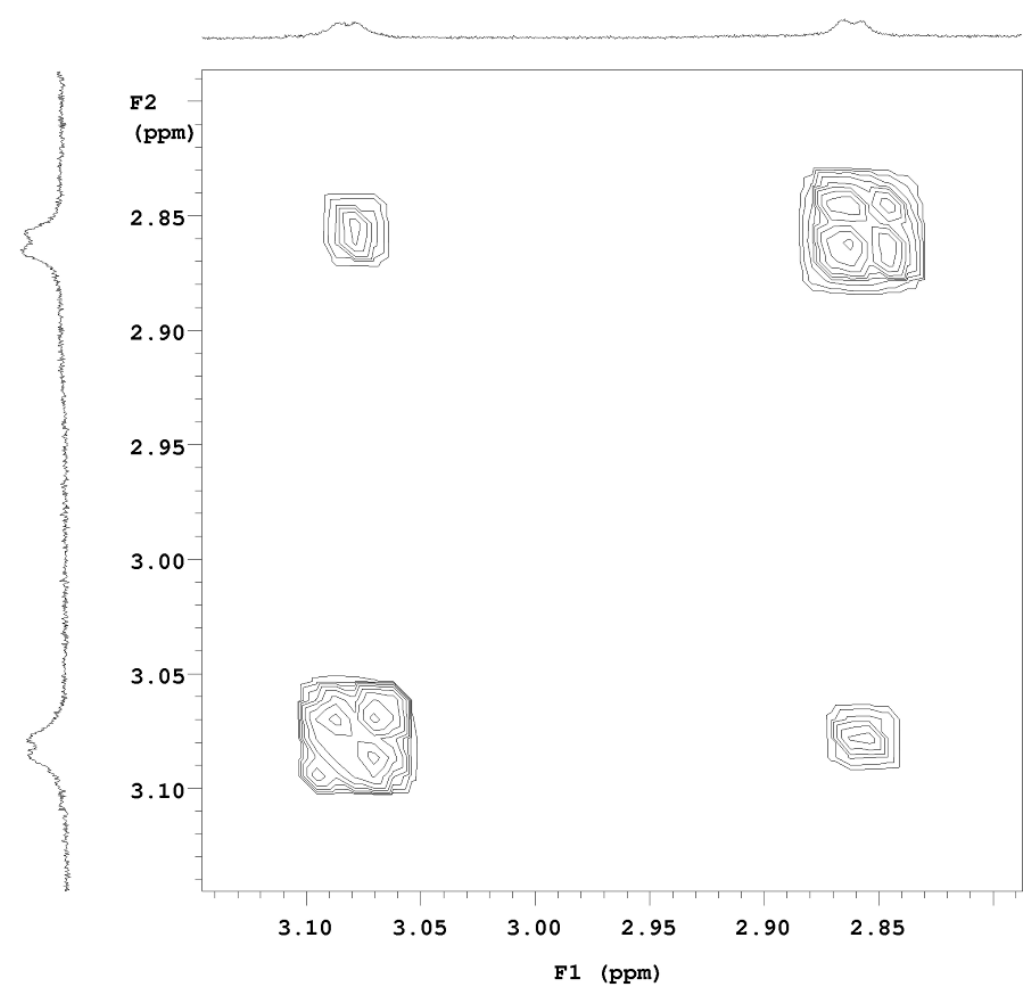

Figure S6. $\mathrm{H}\left(1^{\prime}, 10^{\prime}\right)_{\mathrm{A}}$ and $\mathrm{H}\left(1^{\prime}, 10^{\prime}\right)_{\mathrm{B}}$ protons in ${ }^{1} \mathrm{H},{ }^{1} \mathrm{H}$ gCOSY spectrum of partially epoxidated (1\% conversion) cis, syndiotactic poly(MPCP). 


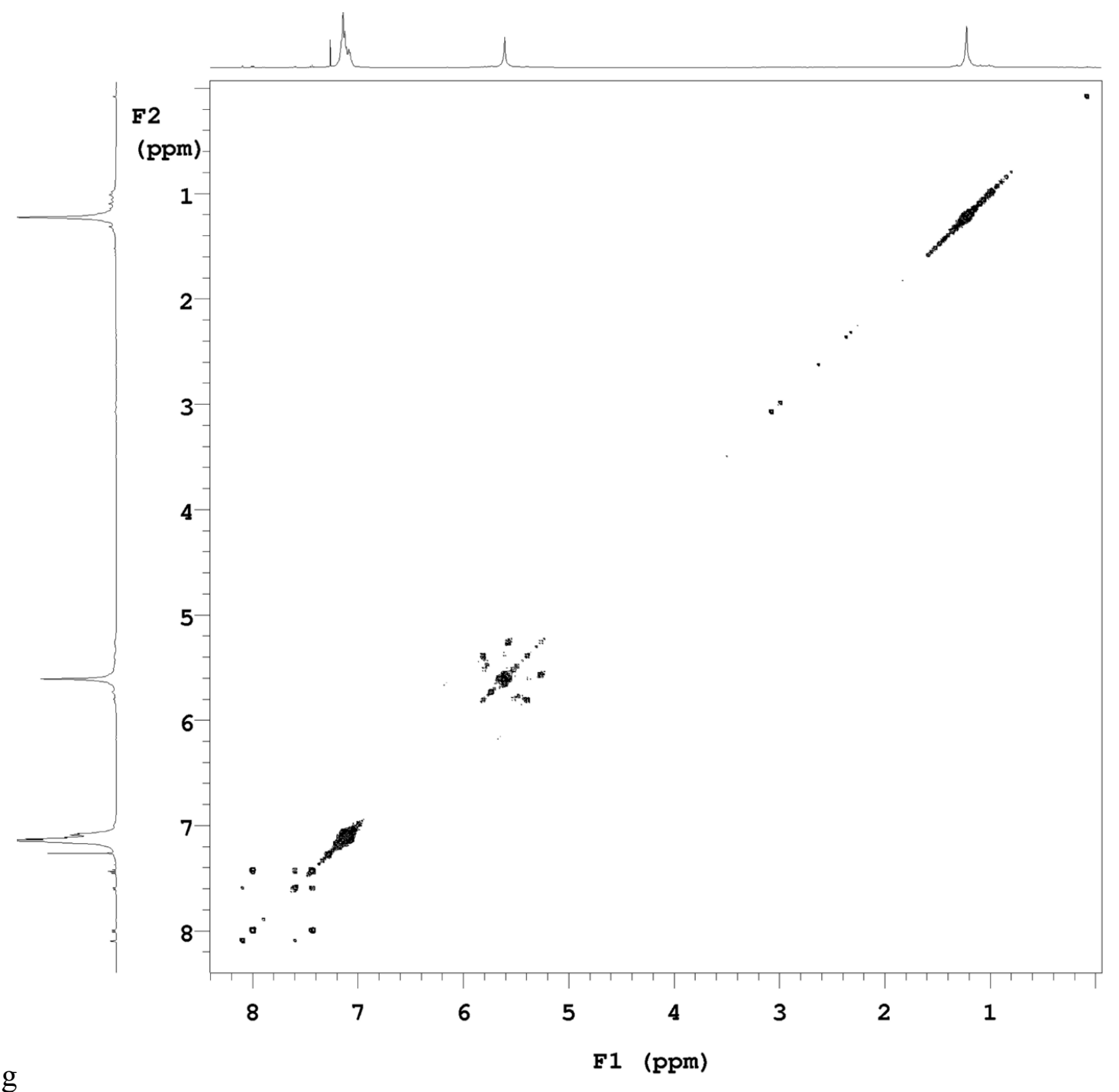

Figure S7. ${ }^{1} \mathrm{H},{ }^{1} \mathrm{H}$ gCOSY spectrum of partially epoxidated $(1.5 \%$ conversion $)$ cis, isotactic poly(MPCP). 


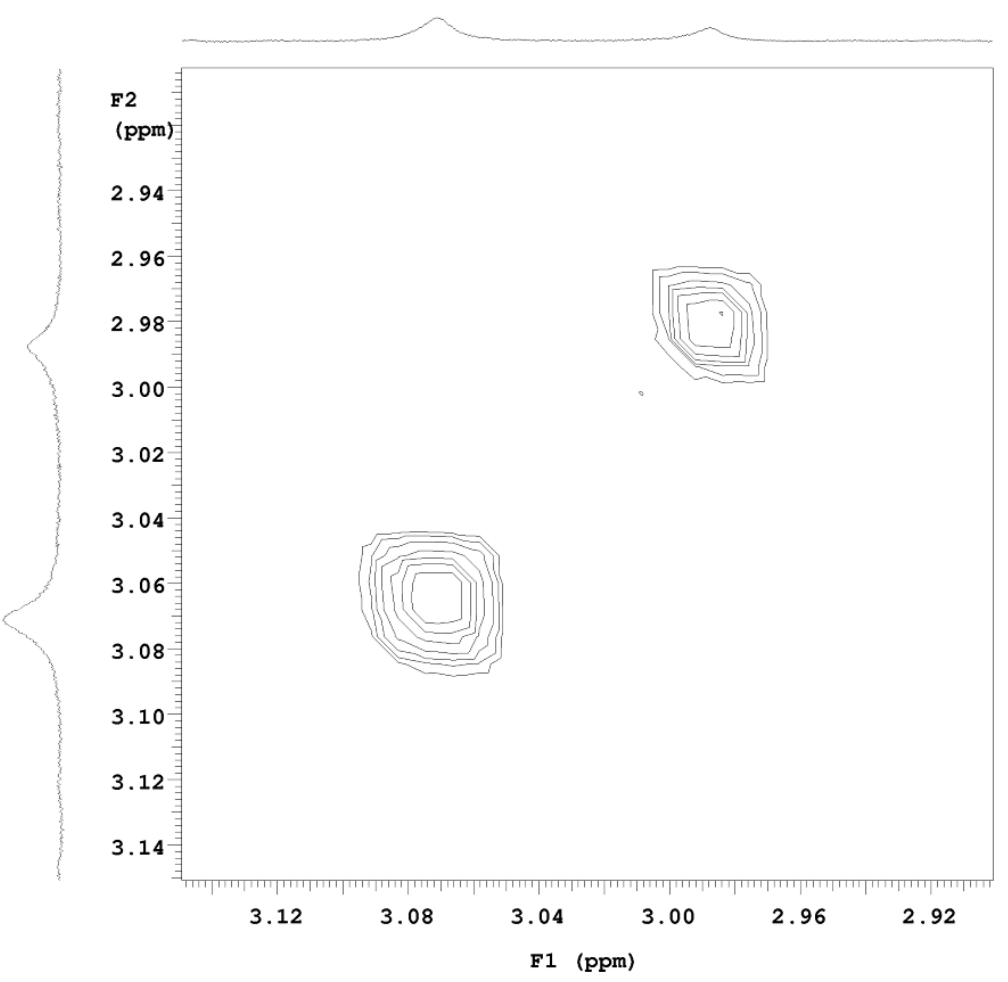

Figure S8. $\mathrm{H}\left(1^{\prime}, 10^{\prime}\right)_{\mathrm{A}}$ and $\mathrm{H}\left(1^{\prime}, 10^{\prime}\right)_{\mathrm{B}}$ protons in ${ }^{1} \mathrm{H},{ }^{1} \mathrm{H}$ gCOSY spectrum of partially epoxidated (1.5\% conversion) cis, isotactic poly(MPCP). 
Epoxidation of poly(endo,anti-tetracyclododecene)

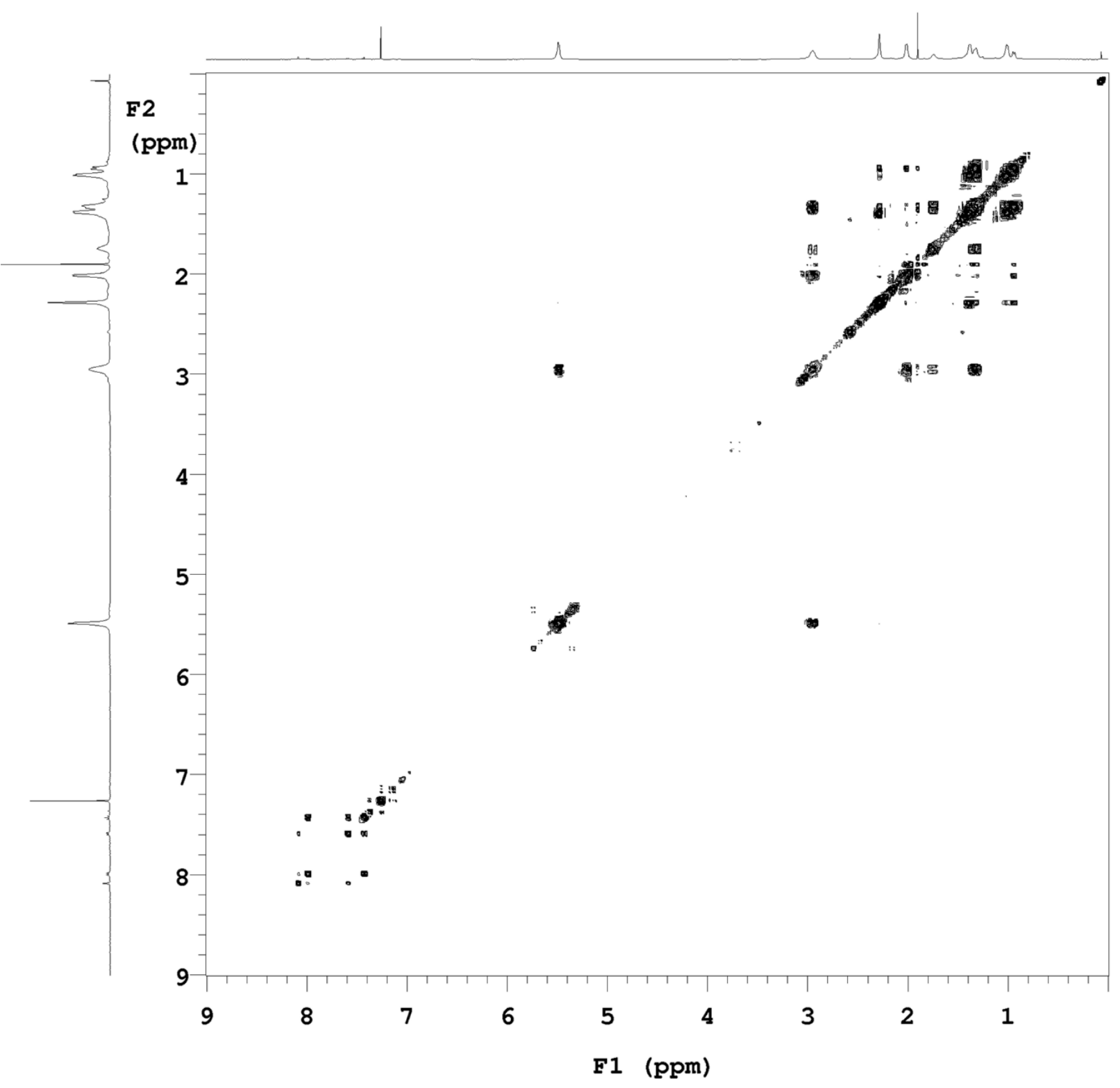

Figure S9. ${ }^{1} \mathrm{H},{ }^{1} \mathrm{H}$ gCOSY spectrum of partially epoxidated (7\% conversion) cis, syndiotactic poly(TCD) with decoupling of the methine protons $\mathrm{H}\left(2^{\prime}, 5^{\prime}\right)$ at $1.90 \mathrm{ppm}$. 


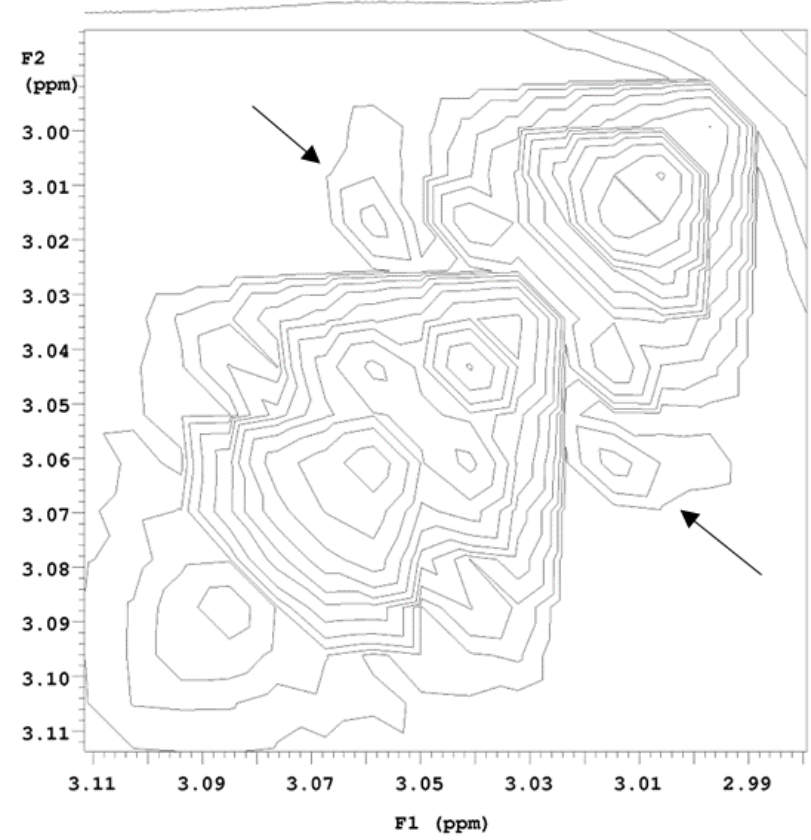

Figure S10. $\mathrm{H}\left(1^{\prime}, 6^{\prime}\right)_{\mathrm{A}}$ and $\mathrm{H}\left(1^{\prime}, 6^{\prime}\right)_{\mathrm{B}}$ protons in ${ }^{1} \mathrm{H},{ }^{1} \mathrm{H}$ gCOSY spectrum of partially epoxidated ( $7 \%$ conversion) cis, syndiotactic poly(TCD) with decoupling of the methine protons $\mathrm{H}\left(2^{\prime}, 5^{\prime}\right)$ at $1.90 \mathrm{ppm}$. 


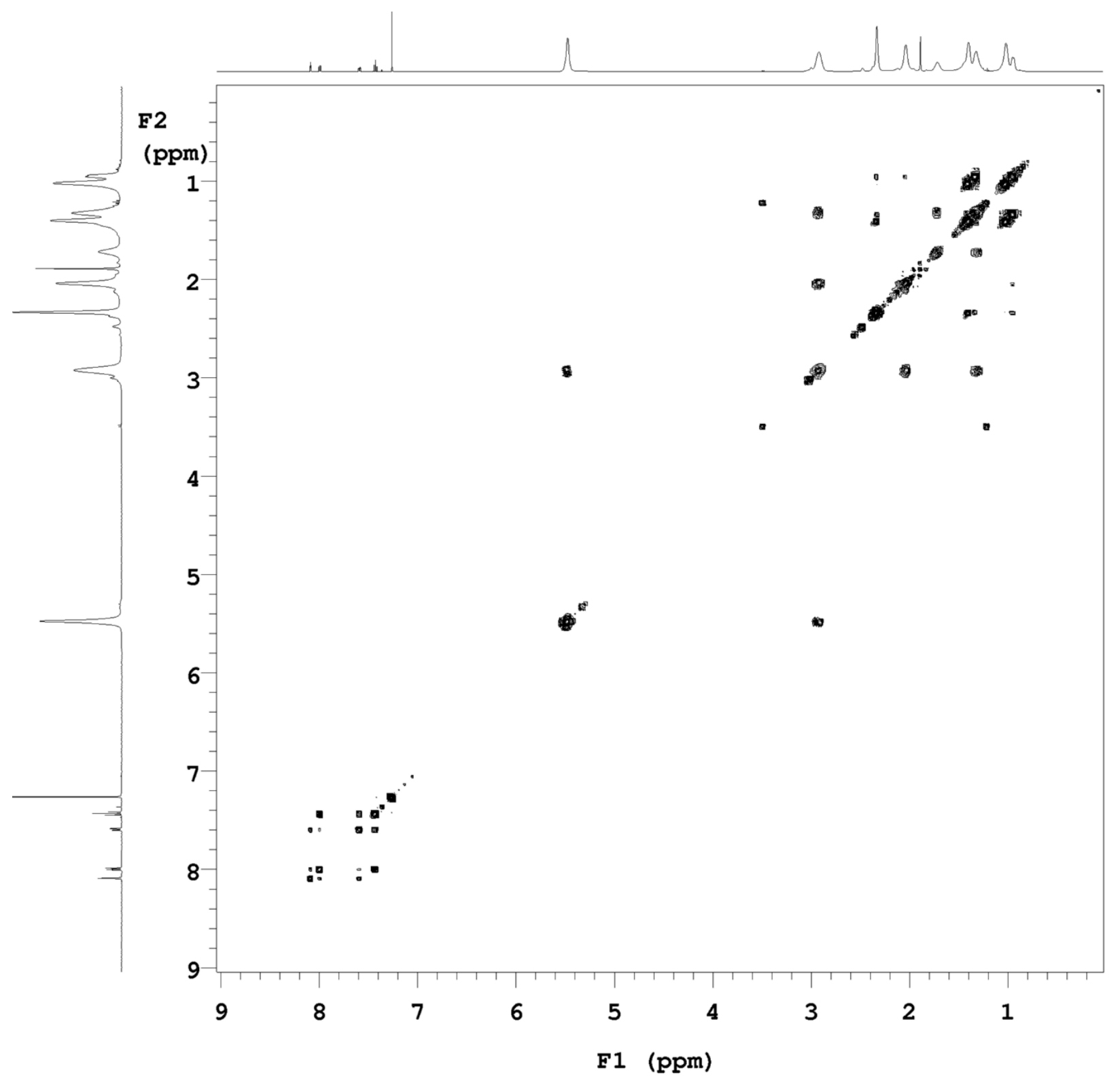

Figure S11. ${ }^{1} \mathrm{H},{ }^{1} \mathrm{H}$ gCOSY spectrum of partially epoxidated (11\% conversion) cis, isotactic poly(TCD) with decoupling of the methine protons $\mathrm{H}\left(2^{\prime}, 5^{\prime}\right)$ at $1.89 \mathrm{ppm}$. 


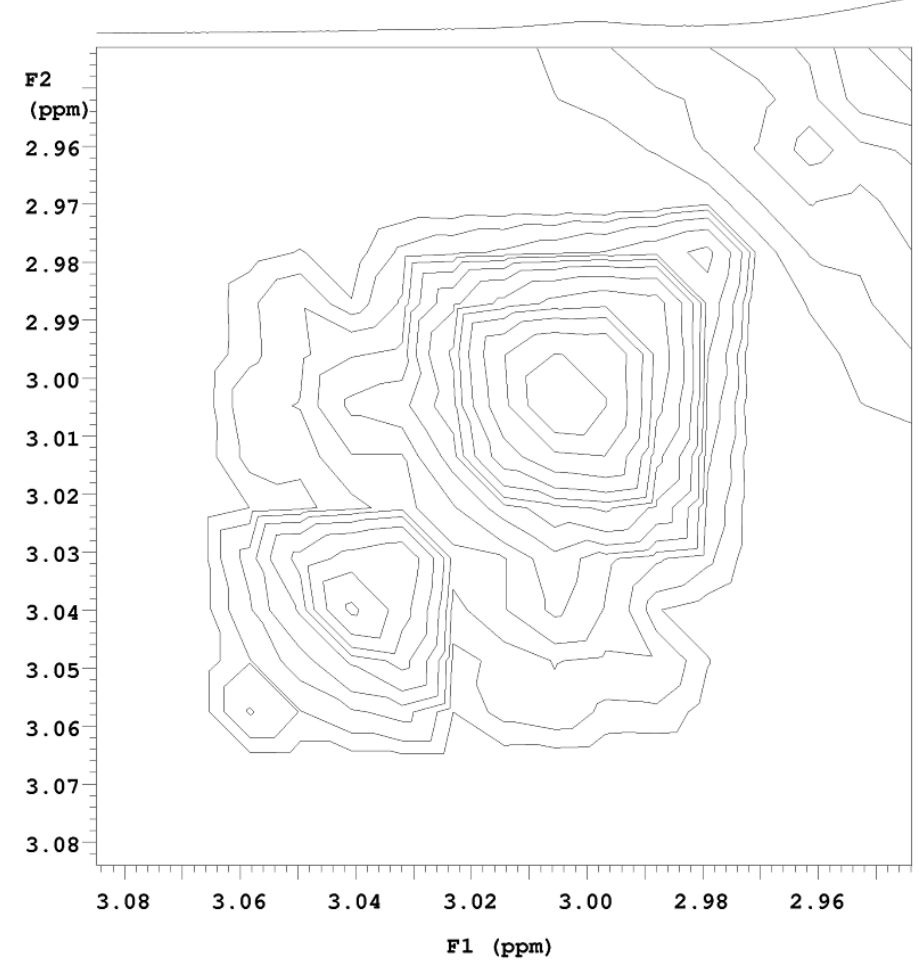

Figure S12. $\mathrm{H}\left(1^{\prime}, 6^{\prime}\right)_{\mathrm{A}}$ and $\mathrm{H}\left(1^{\prime}, 6^{\prime}\right)_{\mathrm{B}}$ protons in ${ }^{1} \mathrm{H},{ }^{1} \mathrm{H}$ gCOSY spectrum of partially epoxidated (11\% conversion) cis, isotactic poly(TCD) with decoupling of the methine proton $\mathrm{H}\left(2^{\prime}, 5^{\prime}\right)$ at $1.89 \mathrm{ppm}$.

\section{References}

\footnotetext{
${ }^{1}$ Autenrieth, B.; Jeong, H.; Forrest, W. P.; Axtell, J. C.; Ota, A.; Lehr, T.; Buchmeiser, M. R.; Schrock, R. R. Macromolecules, in press. (b) Autenrieth, B.; Schrock, R. R.

Macromolecules 2015, asap April 7, DOI: 10.1021/acs.macromol.5b00161.

${ }^{2}$ Flook, M. M.; Gerber, L. C. H.; Debelouchina, G. T.; Schrock, R. R. Macromolecules 2010, 43, 7515 .
}

${ }^{3}$ Singh, R.; Schrock, R. R. Macromolecules 2008, 41, 2990. 